\title{
Beyond the project cycle: an evaluation of agroforestry adoption and diffusion over the medium term in a south Indian village
}

Brockington, J.D.; Harris, I.M.; Brook, R.M.

\section{Agroforestry Systems}

DOI:

$10.1007 / \mathrm{s} 10457-015-9872-0$

Published: 01/06/2016

Peer reviewed version

Cyswllt i'r cyhoeddiad / Link to publication

Dyfyniad o'r fersiwn a gyhoeddwyd / Citation for published version (APA):

Brockington, J. D., Harris, I. M., \& Brook, R. M. (2016). Beyond the project cycle: an evaluation of agroforestry adoption and diffusion over the medium term in a south Indian village. Agroforestry Systems, 90(3), 489-508. https://doi.org/10.1007/s10457-015-9872-0

\section{Hawliau Cyffredinol / General rights}

Copyright and moral rights for the publications made accessible in the public portal are retained by the authors and/or other copyright owners and it is a condition of accessing publications that users recognise and abide by the legal requirements associated with these rights. study or research.

download and print one copy of any publication from the public portal for the purpose of private

- You may not further distribute the material or use it for any profit-making activity or commercial gain

- You may freely distribute the URL identifying the publication in the public portal ?

Take down policy

The final publication is available at Springer via http://dx.doi.org/10.1007/s10457-015-9872-0

Take down policy

If you believe that this document breaches copyright please contact us providing details, and we will remove access to the work immediately and investigate your claim. 


\title{
Beyond the project cycle: an evaluation of agroforestry adoption and diffusion over the medium term in a south Indian village
}

\author{
James D. Brockington, Ian M. Harris and Robert M. Brook \\ J.D. Brockington \& I.M. Harris \& R.M. Brook \\ School of Environment, Natural Resources and Geography (SENRGY), Bangor University, Bangor, Gwynedd, \\ LL57 2UW, UK
}

Corresponding author: j.brockington@bangor.ac.uk

\begin{abstract}
Few studies explicitly assess the temporal and spatial dynamics of agroforestry adoption occurring beyond the project cycle. Where ex-post evaluations are published, abandonment of introduced agroforestry after project cessation is often reported. This paper presents an analysis of agroforestry adoption in a poor, peri-urban village in semi-arid south India, where $97 \%$ of initial adopters had retained their plots six to eight years after implementation. The intervention was facilitated by BAIF, an Indian non-governmental organisation specialising in natural resource management. The complex technological package promoted was known as 'wadi' and comprised fruit trees planted in crop fields, with a boundary of multi-purpose trees and integrated soil and water conservation measures. Sixty four agroforestry plots belonging to 43 households were surveyed in 2010/11 and interviews were held with both adopting and non-adopting farmers. Beyond retention, a quarter of adopters had expanded the practice on to additional areas of land and some diffusion to initially non-adopting farmers had also occurred. Adopters were found to have modified the practice to suit their own objectives, capabilities and constraints, highlighting that adoption is more than a simple binary choice. The study demonstrates the importance of external support for adoption of agroforestry. The intervention was not, however, particularly pro-poor with adoption occurring disproportionately among relatively wealthier households with larger landholdings. Where poorer households adopted, this tended to occur later. Participation was entirely voluntary and, by 2011 , conversion of suitable farmland to agroforestry had reached $18 \%$; while beneficial to individual adopters, this patchy coverage arguably limits the potential for enhanced ecosystem service provision at landscape-scale.
\end{abstract}

Keywords: Adaptation; Adoption dynamics; BAIF wadi; Diffusion; Ex-post evaluation; Fruit-based agroforestry

$\begin{array}{ll}\text { Abbreviations } & \\ \text { BAIF } & \text { BAIF Development Research Foundation } \\ \text { DFID } & \text { Department for International Development (UK) } \\ \text { GPS } & \text { Global positioning system } \\ \text { KML } & \text { Keyhole Markup Language } \\ \text { MPT } & \text { Multi-purpose tree } \\ \text { NABARD } & \text { National Bank for Agriculture and Rural Development (India) } \\ \text { NGO } & \text { Non-governmental organisation } \\ \text { NRM } & \text { Natural resource management } \\ \text { NRSP } & \text { Natural Resources Systems Programme } \\ \text { PUI } & \text { Peri-urban interface } \\ \text { SWC } & \text { Soil and water conservation } \\ \text { TDF } & \text { Tribal Development Fund }\end{array}$




\section{Acknowledgements}

The authors acknowledge funding from the UK Department of International Development (DFID), Natural Resources Systems Programme, project R8084. The views presented here, however, do not necessarily reflect those of DFID. Thanks go to the Tropical Agricultural Association (TAA) whose financial support allowed the first author to conduct two months of fieldwork in the summer of 2010 and to BAIF for their willingness to host the research and facilitate logistical arrangements. The authors are also grateful to Dr Sangeetha Purushothaman for her valuable inputs, to Meera Halkatti, R.B. Hiremath and Y.N. Somangouda for their help in data collection, and to the anonymous reviewers for their perceptive comments. 


\section{Introduction}

2

3

4

5

6

7

8

9

The potential of agroforestry to intensify smallholder production systems, contribute to food security and poverty reduction, and enhance the delivery of critical ecosystem services is well-documented (De Schutter 2010; Garrity 2004; Jose 2009; McIntyre et al. 2009; Pretty et al. 2011). Substantial investment in agroforestry research and development since the 1980s has resulted in impressive scientific and technological advances (Atangana et al. 2014; Sanchez 1995). However, extension efforts appear to have achieved limited success to date, with various commentators highlighting the slow and uneven nature of agroforestry adoption (Jerneck and Olsson 2013; Kiptot et al. 2007; Meijer et al. 2014; Mercer 2004; Pattanayak et al. 2003; Shiferaw et al. 2009). Rigorous adoption studies have proliferated over the past two decades seeking to explain the factors that constrain uptake. Most have employed an econometric approach with regression models based on household survey data derived from a single snapshot in time (Pattanayak et al. 2003). Such studies have generated important insights relating to farmer decision-making and the key determinants - e.g. farmer preferences, resource endowments, market incentives, bio-physical factors, and risk and uncertainty (Pattanayak et al. 2003) - that influence initial uptake of promoted technologies. This approach alone, however, is insufficient if we are to advance our understanding of the complexity of long-run adoption dynamics (Kiptot et al. 2007). Addressing this point seems of crucial importance since, as Mercer (2004: 331) has argued, 'agroforestry systems can contribute to sustainable land use only if they are adopted and maintained over long time periods' (emphasis added).

Agroforestry is necessarily a long-term investment given the lengthy gestation period required for tree-based practices. While new varieties of annual crops and associated inputs can be evaluated over the course of one or two growing seasons, agroforestry technologies usually require several years before the benefits and costs of the newly introduced tree component can be fully assessed (Franzel and Scherr 2002; Mercer 2004). Agroforestry extension projects, however, tend to be time-bound and resource-constrained and there is rarely the opportunity to monitor and evaluate long-term outcomes occurring beyond the formal project cycle (Scherr and Müller 1990). This creates challenges for adequate assessment of technology adoption since doing so is 'often difficult in the immediate aftermath of a project' (Tripp 2005: 144). Nevertheless the vast majority of studies focus on the early phase of adoption - i.e. that taking place during or soon after an intervention - and therefore neglect the dynamics of adoption and diffusion occurring over longer temporal frames (Kiptot et al. 2007). Recognising that the design and targeting of future extension projects could be enhanced by a better understanding of the adoption process beyond initial uptake, German et al. (2006) advocate the need to 'track the fate' of introduced natural resources management (NRM) technologies such as agroforestry over time.

High rates of discontinuation with trialled agroforestry practices in post-project years have been reported in a number of studies from different parts of the world (Adesina and Chianu 2002; Dahlquist et al. 2007; Mercado et al. 2001; Mercer et al. 2005). It is evident that not all farmers who test new technologies go on to fully adopt them (Keil et al. 2005; Kiptot et al. 2007). This raises questions over whether adoption figures reported in end of project evaluations present an accurate indication of outcomes. Do short-term "successes" lead to sustained changes in land management or do farmers frequently abandon agroforestry after the withdrawal of project support? Conversely, other studies (Browder et al. 2005; Kiptot et al. 2006; Wambugu et al. 2012) report farmer-to-farmer diffusion of introduced technologies taking place, suggesting that in some cases the reported level of adoption attributed to a given intervention might understate longer-term uptake and spread.

In addition to possible abandonment or diffusion, it is also important to consider how introduced practices are implemented, adapted and managed. Figures purporting to quantify the scale of adoption and diffusion can be misleading since they can give the impression that $N$ farmers have adopted $X$ technology in a uniform and standardised manner. It is more likely that farmers experiment with and modify new agricultural and NRM technologies in order to achieve a best fit within their own specific household circumstances and land management objectives (Barrett et al. 2002; de Graaff et al. 2008; Douthwaite et al. 2001). In the case of agroforestry, it has been suggested that 'adaptation is the rule rather than the exception' (Scherr and Müller, 1991: 245). Again, adaptation is a process likely to evolve over extended time periods. 
For these reasons, there is a clear case to be made for revisiting agroforestry project sites some years after interventions have ended, in order to assess the temporal dynamics of adoption, adaptation and diffusion occurring beyond the project cycle. This paper addresses this gap, reporting upon the findings of a follow-up case study conducted in 2010 in one south Indian village, where an agroforestry project - funded by the UK Department for International Development (DFID) - was implemented between 2001 and 2005. The primary aim of the study was to ascertain what remained of the agroforestry plots established with project support. Assuming that at least some of these plots were still in existence, the secondary aim was to examine how the introduced practice was being managed by adopting farmers and whether diffusion to other households not involved in the original project had occurred. The paper consists of two parts: a description of the initial agroforestry extension effort and the ex-post survey and analysis.

\section{$59 \quad$ Research context}

60 Natural resource management (NRM) and livelihoods in the peri-urban interface of Hubli Dharwad, 61 India

62 From the mid-1990s, under the Natural Resource Systems Programme (NRSP), DFID funded a series of linked research projects in the peri-urban interface (PUI) of Hubli-Dharwad, a twin city in northern Karnataka. Led by a multi-disciplinary team of natural and social scientists from UK universities in collaboration with local academics and NGOs, the research explored the implications of urbanisation for NRM and livelihoods strategies of the poor living in the surrounding area. The research showed that management of natural resources is particularly challenging in the peri-urban context (Brook et al. 2003). Proximity to the city creates opportunities for non-farm employment which is attractive given typically higher wage rates in comparison to rural labouring; wage competition, however, results in difficulties for farmers to hire labour at rates they can afford to pay and can thus negatively impact on farm management (Nunan and Shindhe 2003). Anecdotal evidence suggests that a growing number of farmers neglect their agricultural enterprises in favour of alternative occupations or supplementary income in the city. The proximity of urban markets intensifies the extractive flow of natural resources from villages to the city; urban demand for fuelwood and building poles drives rapid depletion of periurban tree resources and valuable top-soil is removed to supply brick-making industries (Nunan and Shindhe 2003). Degradation of common pool resources is widespread, as evidenced by catchments lacking vegetative cover and water harvesting structures falling into disrepair.

While easy access to urban markets creates opportunities for natural resource-based livelihoods - e.g. the production of perishable goods such as fruits, vegetables and dairy products - the capability to exploit them is socially differentiated. The poor, often lacking in the assets, knowledge and skills required to reorient and/or upscale their production to meet urban demand, tend to remain locked into low-return activities subject to diminishing access to natural capital (Gregory and Mattingly 2009). Recognising this trend led the research team to engage poor local stakeholders in participatory planning for enhanced livelihoods and improved NRM (Halkatti et al. 2003). Measures identified in the planning process included increasing tree cover through agroforestry, rehabilitation of catchments and water harvesting structures, promotion of improved crop varieties, integrated pest management, vermicomposting, small ruminants for income generation and livestock health initiatives. Six pilot villages were selected, action plans were developed and modified, and implementation through local partner NGOs took place from 2001 to 2005. This paper will focus on the outcomes of agroforestry extension activities conducted in one village - Channapur - by the NGO BAIF Development Research Foundation (hereafter simply BAIF).

\section{BAIF's 'Wadi' agroforestry approach}

BAIF was established in 1967 with a commitment to sustainable development in rural India. The initial focus was on livestock development, particularly improved dairy husbandry, as a strategy for reducing the poverty of small/marginal farmers and the landless. Subsequently its programmes were expanded to take a more holistic approach to NRM and livelihood enhancement through watershed development, farm-forestry, sustainable agriculture, agri-business and formation of people's organisations. During the 1980s, BAIF began to work intensively with tribal communities in the hill tracts of southern Gujarat. Severe degradation of natural resources, particularly of the forest upon which tribal people in the area had traditionally depended, was a 
primary driver of chronic poverty; households were unable to secure their subsistence from small-scale rainfed agriculture in eroded uplands, malnutrition and morbidity rates were high, and distress migration in the dry season was a common survival strategy (BAIF 2011; Bhatt 1990). In an attempt to address this situation, BAIF initiated a holistic tribal development programme (BAIF 2013). The core component was an innovative treebased farming practice - known locally as wadi - which was co-evolved with tribal communities through a people-centred approach to technology development and dissemination (Mahajan et al. 2002).

Wadi comprises agricultural, horticultural and silvicultural components integrated in small (0.2 - 0.6 ha) plots of private farmland (Fig. 1). This complex package is described in some detail here since it is not well-known outside of India and will be the subject of subsequent papers. The following elements are central to wadi agroforestry:

- Wide-spaced rows (typically 8 - 10m apart) of grafted fruit trees as the primary commercial crop and source of supplementary household nutrition;

- Annual subsistence and/or cash crops cultivated in interspaces between fruit trees;

- Multi-purpose trees (MPTs) of mixed species grown along the plot boundaries at approximately $1 \mathrm{~m}$ intervals to act as a windbreak and source of fodder, firewood, green manure, poles and timber;

- Perimeter fencing of the plot using locally available dry woody materials to protect the trees from livestock, particularly during the early years of establishment;

- Physical soil and water conservation (SWC) measures - e.g. bunding, gully plugging, terracing, etc. - to minimize soil erosion and retain moisture in-situ;

- Low-cost water harvesting structures - e.g. farm ponds, small-scale lift irrigation, etc. - to aid plot irrigation.

Wadi agroforestry is usually implemented in conjunction with other community-level interventions. These include the creation (where feasible) of check-dams and open wells for irrigation and potable water, formation of farmer groups and cooperatives for processing and marketing of horticultural and dairy produce, and other income generating activities aimed particularly at households with low natural capital endowments.

Over the past three decades, BAIF has supported in excess of 180,000 households to adopt wadi agroforestry in

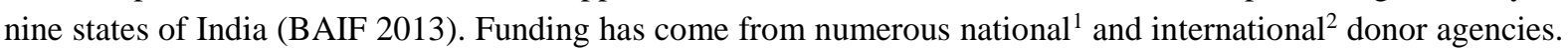
The model has proven adaptable and, with some modification, has been successfully implemented in semi-arid areas as well as the humid hill tracts where it first originated. From 2005, in recognition of the success of BAIF's tribal development programme, the wadi approach became institutionalised through the Tribal Development Fund (TDF) created by the National Bank for Agriculture and Rural Development (NABARD). This fund has been used to support the replication and up-scaling of BAIF's work by a network of NGOs operating nationwide. By 2012, NABARD had sanctioned more than 400 projects through the TDF with the aim of assisting over 300,000 tribal households in 26 states of the country to adopt wadi (website of NABARD ${ }^{3}$ ). Although the majority of wadi projects are implemented with deprived tribal communities, the model has also been successfully applied with small-scale farmers in non-tribal areas.

\section{The intervention}

\section{Site baseline characteristics}

Channapur $\left(15^{\circ} 16^{\prime} \mathrm{N} ; 75^{\circ} 05^{\prime} \mathrm{E}\right)$ is a small village in the Northern Transitional Zone of Karnataka, lying between the Western Ghats and the dry plains of the Deccan Plateau to the east. The region receives an average of $750 \mathrm{~mm}$ of rainfall per annum which falls predominantly during the south-west monsoon (June to September). The village is $13 \mathrm{~km}$ south of the city of Hubli and was selected for inclusion in the project due to the visible extent of material deprivation, manifest in poor physical infrastructure, absence of basic facilities and low natural resource endowments. A preliminary baseline survey conducted in 2001 revealed a total of 252

\footnotetext{
${ }^{1}$ Union Government of India (various ministries and departments); State Governments of Gujarat, Madhya Pradesh, Maharashtra and Rajasthan; National Bank of Agriculture Rural Development (NABARD); Council for the Advancement of People's Action and Rural Technology (CAPART); various philanthropic trusts.

${ }^{2}$ The European Union; German Development Bank - KfW Bankengruppe.

${ }^{3}$ See: oldsite.nabard.org/farm_sector/tdf.asp
} 
households with a population of approximately 1500 people. The village comprised predominantly lower-caste 143 Hindu (68\%) and Muslim (32\%) households. Illiteracy rates were very high, particularly among females at $94 \%$ of those aged six and over. Median household income was just US \$200 per annum. A participatory wealth ranking exercise was conducted early in the project in order to identify the characteristics of wealth/poverty in the village context. Facilitated by NGO staff already well-known in the village, in an open meeting held in the evening to encourage high attendance, participants identified a set of indicators that could be used to rank households according to their relative wealth. Five ranks were defined: rich, upper middle, lower middle, poor and very poor. The proposed indicators comprised mainly measureable aspects of material wealth, such as area of landholding, access to irrigation, number and type of livestock, ownership and size of household dwelling, ownership of vehicles and agricultural equipment, occupations of working members and number of household dependents; more subjective elements such as perceived 'bad habits' and social standing were also included. Using these indicators as a framework, a group of key informants (one from each street in the village) later met to collectively agree and assign a rank to every individual household by sorting name cards into five corresponding piles. The majority (>70\%) of households were ranked 'poor' or 'very poor' (Fig. 2).

Channapur comprises a total of 586 ha of land. State-owned forest (mainly eucalyptus) plantation accounts for 85 ha and a further 120 ha is degraded scrub used for rough grazing and collection of firewood. Discounting areas of physical infrastructure and substantial parcels of uncultivated wasteland, there is around 300 ha of cultivated farmland within the village boundaries. Distribution of landholdings among households living in the village was found to be highly inequitable (Fig. 3). Approximately one third were landless while the mean holding of land-owning households was 1.4 ha (ranging from 0.1 ha to 9.3 ha). Less than $10 \%$ of cultivated land in the village was irrigated in 2001, with a small number of borewell installations belonging to relatively wealthier households. Natural resource-based activities - agriculture and livestock rearing - were the main sources of livelihoods. Around a quarter of individuals derived their primary occupation from farming on their own land while the majority were primarily employed as agricultural labourers. Many individuals, particularly in the long dry season, also commuted to Hubli for work as daily-wage labour in markets, construction sites, factories and haulage enterprises.

The village landscape undulates with slopes of up to $30 \%$. Altitude ranges from $550 \mathrm{~m}$ to $680 \mathrm{~m}$ above sea level, with lower-lying ground to the south and east of the village (the lowland area; Fig. 4) and higher ground to the north and west. The red soils in the area, consisting mainly of eutric nitosols with subsidiary ferric and chromic luvisols, possess a shallow and often eroded quality with a low water holding capacity leading to rapid dryingout once rains cease. Only one crop can typically be grown per annum. Decline of tree cover over preceding decades has contributed to the erosion of soils through increased rainwater run-off, resulting in increased siltingup of village 'tanks' (small reservoirs formed by check dams). In the general absence of irrigation facilities, crop cultivation is dependent upon the vagaries of the south-west monsoon, which has become increasingly erratic in recent years. Cotton was the main cash crop grown in 2001, along with sorghum, millets and groundnut for subsistence and market. Rice was traditionally cultivated in the more fertile low-lying basin to the south and east of the village where fields were often bunded to impound rainfall. Reported crop yields were low and annual incomes of less than US $\$ 100$ /ha were common. Given low returns to investment, farming was becoming less of a priority for many households, especially those with small rainfed holdings.

\section{BAIF's extension approach}

BAIF were already implementing the wadi model successfully through an EU-funded project with around 1000 farmers in a nearby cluster of villages. It was seen as an ideal intervention in the context of Channapur. The objectives were to: (1) increase the total productivity of farming systems through in-situ conservation of resources, (2) enhance soil fertility and reduce dependence on external inputs, (3) help participants to develop more secure sources of food, fuelwood, fodder and green manure, (4) boost incomes through marketable fruits, and thus (5) provide viable land-based alternatives to urban migration. BAIF began by holding a series of public meetings and consultations to promote the concept. Smallholders in the village were initially sceptical about the viability of tree-based farming under rainfed conditions. They observed that although a few wealthier households in the village had converted land to fruit orchards, these were typically large in size and irrigated through borewell installations. To address such concerns, exposure visits to pre-existing rainfed wadi plots 
elsewhere in dryland Karnataka were arranged at no cost to interested farmers. Through a process of dialogue and peer-learning, farmers in Channapur became more confident in the viability of establishing agroforestry on their own lands. Technical instruction was provided through on-farm demonstrations. Uptake of wadi occurred in a staged pattern over three years: 23 households elected to trial the technology in 2002, followed by four more in 2003 and another five in 2004; one household subsequently rejected wadi soon after establishment leaving a total of 31 households managing fledgling wadi plots when the project terminated in 2005 .

BAIF estimated the implementation cost of wadi to have been in the region of US $\$ 100$ per one acre ( 0.4 ha) plot established. Plot layout generally adhered to the typical model (Fig. 1), although flexibility in implementation was permitted to allow for variation in plot size, shape and topography. Simple tools (e.g. spades, pickaxes, clay watering pots) were provided at no cost to the farmers involved, and small financial incentives were offered in lieu of the days of labour expended in preparatory groundworks (e.g. digging planting pits, creating trench-cum-bunds ${ }^{4}$ and excavating farm ponds). While fruit grafts were purchased from trusted sources, a local nursery supplying MPT seedlings was considered to be essential; this was established on an irrigated field belonging to a wealthy household and operated by landless women from the village for a small income. A total of 2,367 fruit grafts and 12,787 MPT seedlings were distributed free of charge to participating households. By the end of 2004, each household involved had planted 470 trees on average, representing a 17fold increase in the number of trees present on their combined lands. Despite severe droughts experienced during 2002 and 2003, reported rates of tree survival by 2005 were impressive, exceeding a target of $75 \%$ survival for fruit trees and $50 \%$ for MPTs. This was attributable to the technical training provided by BAIF project staff in appropriate planting and after-care methods such as planting MPTs on trench-cum-bunds designed to capture rainwater in-situ, seepage irrigation of fruit trees using locally made earthenware pots with a small hole in the base, regular application of organic mulch in shallow basins around the fruit trees and shading using simple structures made from locally available materials. Nineteen households $(60 \%)$ had also used project support to construct farm ponds $(10 \mathrm{~m} \times 10 \mathrm{~m}$ x $3 \mathrm{~m})$ located in the lower part of their wadi plot or adjacent field. These harvest rainwater runoff and serve both to replenish the groundwater table and provide a source of water for protective irrigation of fruit trees.

In 2005, as part of wider efforts to build-in participatory monitoring and evaluation into all of the DFID project interventions, a group discussion and voting session was held with 25 of the wadi adopting farmers present. Farmers' perceptions of wadi were measured according to a set of mutually agreed indicators; the outcome was clear evidence that the project and the introduced technology had been favourably received (Table 1). However, the wadi plots were still in the early establishment phase at this point; as the trees matured over the coming years it was expected that farmers would continue to evaluate the practice in light of management costs and returns from multiple system components. Farmers' perceptions of wadi as a technology were therefore liable to change over time and, although the early signs of success were promising, the long-term sustainability of wadi agroforestry in Channapur was still uncertain.

\section{Methodology}

In 2010, five years after the DFID project activities formally ended, the opportunity arose for the lead author to undertake an ex-post assessment of wadi adoption and management in Channapur. Fieldwork was conducted over eight weeks in June and July 2010 supplemented with short visits in December 2011 and July 2013.

\section{Data collection}

In order to assess what remained of the agroforestry plots established during the project, data were collected through detailed plot surveys. This being a small village, a complete census approach was taken with all agroforestry plots within the village boundary surveyed; thus there was no sampling. Sixty-four plots with planted fruit trees were surveyed by boundary walking with a Garmin Etrex GPS unit to record location and extent. In 61 of these plots, trees were counted (disaggregated by species for fruit trees but not for MPTs due to

\footnotetext{
${ }^{4}$ Trench-cum-bunds are constructed across the slopes of the plot and along field boundaries. Trenches are dug and the excavated soil is used to construct a bund along the lower side of the trench.
} 
time constraints) and observations were recorded relating to the types of intercrops cultivated and the presence/absence of SWC measures and irrigation sources. Short interviews were held with 37 (86\%) of the 43 households whose agroforestry plots had been surveyed. These were usually conducted with the household head, although other family members were sometimes present. They took place either in the agroforestry plot or in the household dwelling and typically lasted around 30 minutes. A predesigned interview schedule was administered through a local field assistant working in the state language of Kannada, with translated responses recorded on paper. Plot survey data was first verified and then additional information was collected on levels of fruit tree mortality and restocking. Further open-questions focused on management practices and challenges, product utilisation and future expectations. Interviews were also conducted with 17 households who had not adopted fruit-based agroforestry to explore the constraints to adoption. Nine of these households were selected on the basis that they had taken part in training and exposure visits provided by BAIF before ultimately deciding against adoption. The others were randomly selected from a list of land-owning households who had been ranked either poor or very poor in the wealth ranking exercise conducted during the intervention. BAIF field staff were also consulted on an informal basis to get useful background information on the project and also to cross-check information emerging from discussions with farmers.

\section{Data analysis}

Quantitative data from plot surveys and information gathered from farmers on mortality and restocking were organised and interrogated using Microsoft Excel and IBM SPSS Statistics. Descriptive statistics are presented in this paper. Qualitative interview data were assembled in a spreadsheet and analysed to identify commonalities and differences in responses. Mapping data collected was visualised for initial verification purposes by converting the GPS locations (recorded as WGS1984 decimal degrees) into .KML (Keyhole Markup Language) locators for display within Google Earth ${ }^{\circledR}$, given the non-availability of backdrop mapping. The KML data were then converted into points within ArcGIS 9.3.1 (ESRI, 2009) and individual locations edited where misalignments appeared against the Google Earth backdrop, visualised using the Arc2Earth (Arc2Earth, 2012) extension. The point data were then used to digitise polygons, where land use and ownership information were attached to the parcel shapefile attribute table records. Areas of individual polygons were then obtained, as the projected Web Mercator referencing system used with Google Earth facilitates geometry calculations. The location of the village boundary, roads, forest plantation, common land and water tanks were also captured using the method outlined. In order to assess elevation of the land parcels, ASTER 30m Global Digital Elevation Model v.2 data (Tachikawa et al. 2011) for the study area were obtained, which were the highest resolution data available. From this and local observations the area defined as lowland was delineated.

\section{Results and discussion}

\section{Adoption and retention of fruit-based agroforestry}

By 2010-11, a total of 40 households residing in Channapur had converted one or more plots of land to fruitbased agroforestry systems. All 31 households that were trialling the BAIF wadi model at the end of the project in 2005 were found to have retained their plots. Nine additional households that had not received BAIF project support had adopted a similar practice on some part of their landholding. Relative wealth (defined by the villagers themselves during the wealth ranking exercise in 2002) was found to be related to the timing and rate of adoption in Channapur (Table 2). Of eligible land-owning households, $67 \%$ of those ranked rich had adopted fruit-based agroforestry compared with $32 \%$ of the two combined middle classes and just $14 \%$ of the combined poor and very poor classes. It is worth noting, however, that households ranked 'rich' in Channapur would not be considered especially wealthy in other villages in the surrounding area.

During the first year of the project, adoption of the introduced wadi practice occurred overwhelmingly among households from the relatively wealthier end of the spectrum (Table 2). Nineteen (91\%) of the 23 households who used BAIF inputs to establish wadi systems in 2002 were ranked in the upper three classes; this number included five of the rich households who had independently established fruit orchards in the 1990s and 18 new adopters. Over the course of the project, the proportion of poorer households participating increased and accounted for 60 percent of all cases of adoption occurring during 2003 and 2004. Six cases of first-time 
adoption were found to have occurred independently of BAIF support either during or after the project. Two cases involved plots established through investment of household capital in the acquisition of planting materials from private nurseries. In the remaining cases, households had used subsidised planting stock made available through a World Bank funded watershed development programme known locally as Sujala (Milne 2007), which operated in the area from 2005 to 2007 . In addition to these new cases of first-time adoption, it is notable that eight households who had adopted wadi during the project had subsequently extended the practice by establishing additional plots. This had been achieved in all cases through the use of subsidised planting materials provided through Sujala.

Wealthier farmers tended to have larger farms, so adoption was similarly found to relate to farm size (Table 3). Thirty two percent of all households with landholdings of one hectare or more had adopted compared to only $13 \%$ of those with holdings of less than one hectare. This suggests a possible threshold in farm size below which farmers considered the risk of trialling the new practice to be particularly acute. Those households that adopted also tended to have a higher proportion of working individuals engaged in agriculture on their own land as a primary occupation, whereas individuals in eligible non-adopting households were mainly engaged as wage labour in agriculture or in the city (Fig. 5). This suggests that households that farm their own land perceived a greater incentive to adopt agroforestry, whereas those depending heavily on other livelihood activities were less inclined to invest resources in this way.

\section{Extent and spatial distribution of plots in the landscape}

The 64 fruit-based agroforestry plots surveyed can be classified into three groups (Table 4): (1) orchards that pre-dated the intervention (before 2002); (2) wadi plots established with BAIF support during the intervention (2002-2004); and (3) wadi-like plots established without BAIF support either during or after the intervention (2002 onwards). BAIF-mediated wadi plots were by far the most numerous, representing roughly two thirds of all agroforestry plots surveyed. They covered a total area of 20.1 ha with a mean plot size of 0.5 ha. Plots created independently of BAIF since 2002 were a similar size - mean 0.4 ha - but were fewer in number and covered only 7.0 ha in total. By comparison, the nine commercial orchard systems that predated the intervention were much larger with a mean size of 2.0 ha.

An area of 45.9 ha of land was found to be under fruit-based agroforestry systems. However, as indicated in Fig. 4 , six of the plots surveyed (4 BAIF wadi plots and 2 pre-existing orchards) lay just beyond the southern boundary of the village. Thus the extent of fruit-based agroforestry within the village boundaries was calculated to be 40.7 ha - or $14 \%$ of total village land estimated to be under cultivation. The plots were largely concentrated on the more marginal upland areas to the north and west of the village (Fig. 4), revealing a clear preference by farmers not to plant trees in the lower-lying and more fertile areas to the south-east of the village that are traditionally associated with rice paddy. If this lowland area of ca. 90 ha is therefore excluded from the calculation, the coverage of fruit-based agroforestry rises to $18 \%$ of all less-favourable agricultural land available in the village. Within farms, as shown in Fig. 6, considerable variation was found in the extent of land converted to fruit tree-based agroforestry (all types). This was the case both in absolute terms, with households converting anywhere between 0.1 ha and 7.9 ha of land, and in proportional terms, with anywhere between $5 \%$ and $100 \%$ (mean $49.8 \%$ ) of their total landholding being converted. Among adopters there was no clear relationship between area of landholding and proportion of land converted to agroforestry.

\section{Tree densities}

During the intervention, BAIF recommended that farmers establish one acre ( 0.4 ha) wadi plots with 40 fruit trees (or 100 trees /ha) and 500-600 boundary-planted MPTs (or roughly 150 trees / 100 metres). By the time of the ex-post analysis, in 2010, project adopters were found on average to be managing the fruit component of their wadi plots at slightly higher than recommended density (mean 114 fruit trees /ha). There was substantial variation, however, with densities ranging from just 39 fruit trees /ha to 287 trees /ha. Plots established independently of BAIF since 2002 had a similar average density (mean 124 fruit trees /ha) but ever greater variability (ranging from 21 to 415 fruit trees /ha). Plots that pre-dated the BAIF intervention were managed at much higher average density (mean 214 fruit trees /ha), again with plot-level variation (ranging from of 90 to 316 fruit trees /ha). 
The substantial variation in plot-level densities of fruit trees can be seen as a consequence of both choices made by individual farmers over plot-layout and differential levels of subsequent mortality and restocking. BAIF's recommended planting density is designed to allow sufficient space between rows of fruit trees for continued cultivation of agricultural intercrops. However, during interviews with adopting farmers, some reported having planted at lower density in order to allow wider spaces for easier and prolonged intercropping. In contrast, others had chosen to plant at higher density, offsetting the loss of some additional space for intercropping against larger expected fruit production in the future. Plots with particularly high densities ( $>150 / \mathrm{ha})$ resembled more traditional orchards, where farmers clearly prioritised the fruit trees and accepted substantially reduced space for agricultural production. Mortality had occurred in all plots, reportedly due to combinations of drought, pest and disease, and fire (both accidental and deliberate arson), but levels were highly variable. It is notable that in BAIF plots with fewer than 75 fruit trees per hectare $(n=12)$, levels of reported mortality were particularly high with around $45 \%$ of fruit trees planted having been lost on average. It is also notable that efforts to re-stock were reported in less than half of these plots and at very low levels, with farmers planting an average of just five (range: 0 - 21) additional fruit trees. Discussions with farmers and BAIF staff indicated that such outcomes were typically the result of neglect, owing to issues including disputes over ownership, shortages of labour (due to old-age, ill-health, alcoholism, etc.) or prioritisation of off-farm livelihood activities. The majority of BAIF plots - those with densities of more than 75 fruit trees per hectare $(n=26)$ - were generally under more committed management. Reported mortality of fruit trees was lower, with losses of around $25 \%$ on average, and some degree of restocking had been attempted in all plots, with farmers planting an average of 19 (range: $4-41$ ) additional fruit trees.

Average densities of boundary-planted MPTs were lower than recommended by BAIF in all three plot classes.

\section{Tree species}

Table 5 provides a complete list of all tree species recorded in the agroforestry plots surveyed. Mangifera indica (mango) and Manilkara zapota (sapota) were the most abundant fruit trees in the BAIF-mediated wadi plots. BAIF promoted these species due to their economic value as commercial crops and their known suitability for cultivation within this agro-climatic zone. Of the two, mango proved most popular with farmers, especially in rainfed systems ( $70 \%$ of wadi plots) since it was perceived to be more tolerant of a low moisture regime than sapota. In contrast, Psidium guajava (guava) and sapota were the two choice species in pre-existing orchard systems, where borewell irrigation ( $100 \%$ of plots) gave farmers greater confidence to cultivate these more "water-hungry" crops. Non-BAIF plots established since 2002 contained roughly equal numbers of these three species but, again, mango was the preferred crop in rainfed systems (53\% of plots) while sapota and guava dominated in the irrigated systems (47\% of plots). Plot-level richness of fruit species in BAIF-mediated wadi plots was found, on average, to be slightly higher ( 4.2 species) than recorded in the pre-existing orchard systems (4 species) and substantially greater than in non-BAIF plots established since 2002 (2.4 species). BAIF wadi plots were also observed to be richest in species of MPTs grown. All wadi plots contained a mix of MPT species drawn from twelve promoted by BAIF during the intervention. In contrast, in all non-BAIF plots the range of species observed was much narrower and one species - Tectona grandis (teak) - was overwhelmingly dominant due to its known value as high-grade timber and the ready availability of seedlings in local nurseries. The overall richness of tree species observed in BAIF wadi plots was an outcome of both the deliberately broad mix of species offered by BAIF during the project leading to diverse systems from the outset, combined with the 
diversification strategy employed by some farmers when planting additional species into their plots to supply household demand for particular products (e.g. fruits such as coconut, lemon and papaya).

\section{Soil and water conservation measures}

A key feature of BAIF's wadi model is the integration of SWC measures designed to reduce soil erosion and retain scarce rainwater in-situ. The need for SWC is evidently more pronounced in rainfed plots than in those with a source of irrigation where access to water "on-tap" removes or substantially reduces the constraint on system productivity posed by scarce and erratic rainfall. As noted, $30 \%$ of BAIF wadi plots were irrigated by borewell and here farmers had tended not to prioritise SWC measures, although some had constructed farm ponds with a view to aiding groundwater recharge. By contrast, in many rainfed plots farmers were observed to be actively maintaining farm ponds, trench-cum-bunds and basins mulched with organic matter around fruit trees. However, this was not universally true; some farmers had decided against installing these measures, while others reported having deliberately removed them (by filling in trenches and ponds, levelling bunds, etc.) after the project in order to maximise available space for crop cultivation. In pre-existing orchard systems, borewell irrigation was ubiquitous and SWC measures were not common. In plots created independently of BAIF since 2002, more than fifty percent were borewell irrigated but field bunds were present in most cases, having been incentivised under the Sujala watershed project.

\section{Agricultural intercrops}

Intercropping was practiced to varying degrees in all but two of the 38 BAIF wadi plots and in all of the nonBAIF plots created since 2002. Maize and cotton were the predominant choices of crop along with sorghum, groundnut, various millets and vegetables. In pre-project orchards, despite the high density of fruit trees, intercropping was still practiced to a limited extent on five of the nine plots with maize the dominant choice of crop. With fruit trees reaching maturity (12-18 years old) however, space and light available to intercrops had substantially diminished. Discussions with farmers revealed that the increasingly large volumes of fruit produced in these plots more than compensated for reduced crop yields. In wadi plots, canopy closure was not yet an issue although there had been an inevitable loss of space for crop cultivation. This was more pronounced in plots with higher densities of fruit trees and where farm ponds and trench-cum-bunds were maintained. Differences of opinion regarding the effects of trees and SWC measures on crop performance emerged during interviews with farmers; many felt that wadi plots were now more productive, due to perceived improvements in soil fertility and/or water availability, while others felt that a reduction of space and competition between trees and crops had a negative effect on output. Comparison was not straightforward as many farmers reported varying the choice of intercrop from one year to the next and none kept written records of plot-level crop yields.

\section{Tree products}

From field observations and discussions with farmers, it was evident that wadi plots were beginning to provide adopting households with tree products. Mango and sapota trees had started fruiting from the fifth or sixth year after planting, but reported yields were variable and of low magnitude. This was primarily due to the trees still being juvenile although, during interviews, farmers also highlighted a number of challenges relating to the management and productivity of fruit trees. A significant issue, mentioned by $11(29 \%)$ farmers, was lack of water supply in rainfed plots for protective irrigation of fruit trees during the dry summer months. Another frequently reported concern, mentioned by seven farmers (18\%), was over unseasonal rains and heavy morning fogs occurring during the mango flowering season, which reputedly caused flowers to shed thereby reducing fruit yield. Theft of fruit was also reported in a number of interviews, although farmers indicated that this was at generally low levels and attributed it mainly to children from the village. On the whole, farmers were positive over future prospects, with substantial increases in fruit yields anticipated in the coming years as the trees approach maturity. Despite the limited volumes produced by the time of the field work, around one quarter of households reported having been able to sell quantities of fruit in local markets. For the majority, however, fruit produced at this stage was used only to provide a valuable source of supplementary household nutrition, particularly for young children. In the orchard plots that predated the BAIF intervention, fruit production was considerably greater due to both the relative maturity of these systems (12-18 years old) and the typically higher densities of fruit trees present. Farmers involved reported that annual earnings from sales of fruit were in the 
region of US $\$ 500$ /ha of orchard. Four had entered into contractual relations with local middlemen who supplied labour to guard, harvest and market the fruit in return for an agreed share of the profits.

The majority of wadi adopters reported that they were coppicing and pruning boundary-planted MPTs to provide a regular source of firewood from their own fields and supplement or replace collection from degraded communal scrubland a kilometre or more to the east of the village. Tree leaves were used as green manure and for fodder, and some farmers were also growing grasses and Stylosanthes hamata for fodder along internal plot bunds. Harvesting of MPTs for sale of timber had not yet occurred, although a number of farmers reported having coppiced poles for use in constructing farm implements and in repairing or renovating household dwellings. It was clear from discussions with farmers that they were aware of the future timber value of the trees - particularly teak - with many expressing the view that these provide a form of security against future contingencies and are an asset that can be passed down to their children (c.f. Chambers and Leach 1989). Given the low numbers of MPTs in the older orchard systems, few other tree products were generated.

\section{Reasons for non-adoption}

Of the 17 non-adopting farmers interviewed, the majority (70\%) were from the poor and very poor wealth classes. Principal among the reasons for non-adoption during the BAIF intervention were concerns regarding shortages of water, land and labour (Table 6). Drought and the absence of irrigation facilities had put off many of these farmers who doubted the practice would be profitable under rainfed conditions. Farmers also reported having been reluctant to convert land since they only had small landholdings and relied upon their existing agriculture for subsistence; they feared that crop yields may decline substantially when trees were introduced and felt they could not afford to take the risk. Lack of available household labour was also an issue in some households, either where there were few healthy working members or where existing livelihood activities were perceived to leave insufficient resources to invest in trialling and adopting a new practice. Work in the city was often seen as a constraint to investing in the land. Interestingly, when asked about their non-adoption in the years after the BAIF project, some farmers expressed regret at having passed up on the opportunity. While labour availability remained a commonly cited constraint to adoption, the most common reason offered concerned lack of available capital to invest in acquiring the planting materials from commercial nurseries. Having seen small rainfed systems develop successfully on the lands of neighbours, these farmers no longer considered the availability of land or water to be a major limiting factor. But investing scarce household resources in establishing a wadi-like system without any external support was a risk few seemed willing (or able) to take.

\section{Conclusions}

In reflecting on our findings, we will use the recommendation of Scherr and Müller (1991: 243) 'to distinguish three levels of "agroforestry adoption" in evaluating project impact:

1) willingness to test new agroforestry components and practices, i.e., to establish the new systems on the farm on an experimental basis;

2) willingness to maintain and manage the new agroforestry system, i.e., trees are not uprooted or abandoned, intercropping is continued, and the farmer continues to observe and evaluate costs and benefits of managing the system;

3) extension of the agroforestry system on other pieces of land, or re-establishment at the end of the life-cycle of the longest-growing component, i.e., acceptance of the technology as part of the farming system.'

In the case of Channapur, 32 households had achieved the first level of adoption by showing willingness to test the new wadi agroforestry practice on some part of their farm. In respect of the second level of adoption, the BAIF wadi intervention has achieved remarkable success. Only one farmer subsequently abandoned the practice and this occurred during the project itself. The remaining 31 adopting households (97\%) retained their wadi plots six to eight years after initial establishment. However, in 2010, the process of evaluating the costs and benefits of managing the plots was still ongoing. Increasing availability of tree products for household consumption was valued, but market sales were low due to the typically small volumes of production. Higher 
incomes were expected in the coming years as the tree components reach maturity, but there was still much uncertainty over long-term financial returns. While the orchards that pre-dated the BAIF intervention provide some indication of the possible magnitude of future fruit production, the fact that these systems are typically large, high-density plantations irrigated through borewell means they are not directly comparable to the majority of wadi plots that are small, lower-density, rainfed systems. Due to this uncertainty, it is conceivable that future abandonment could still occur should the wadi systems fail to meet farmers' expectations. This emphasises the need to track introduced technologies over extended periods if the long-run impacts of agroforestry interventions are to be fully assessed.

Beyond retention, eight project adopters $(25 \%)$ were found to have created additional plots thereby increasing the extent of the practice on their landholdings and, thus, achieving the third level of adoption. There was also evidence of diffusion to other farmers who had not initially adopted. That extension and diffusion had occurred gives strong indication that farmers in Channapur possess increasing confidence in the wadi practice. While it is the case that most adopters have not taken up wadi on a whole-farm scale, converting on average around 50\% of their landholdings, this form of agroforestry does appear to have been accepted as a long-term component of farming systems in the village. That said, it should be noted that the vast majority of cases of extension and diffusion occurred using heavily subsidised planting materials from the unrelated Sujala watershed project, rather than through investment of households' own financial capital. The limited adoption and expansion observed without external programme inputs points to the importance of outside agency in facilitating agroforestry adoption, through activities such as farmer mobilisation, technical support and distribution of quality germplasm.

In assessing management practices, considerable variability was observed among adopting households. This was most evident in terms of plot-level tree densities, where lower densities reflected either difficulties in management (high mortality and low levels of restocking) or a strategy to minimise loss of space for crop cultivation, and higher densities reflected greater commitment to managing the new tree component (lower mortality and/or investment in restocking) and a strategy to maximise output of tree products. Farmers' selection of fruit tree species appears to have been heavily influenced by the availability of water; those with access to irrigation facilities tended to prefer sapota and guava for their higher economic value, while those with rainfed systems favoured mango as it was considered to be less water-demanding and to have greater tolerance to drought-conditions. Farmers with irrigation facilities also tended to place less importance on SWC measures given the year-round availability of water. While adoption of SWC measures was more prevalent among farmers lacking access to irrigation, such measures were not observed in all rainfed plots and this seemed to reflect differences of opinion regarding the costs and benefits of installation and maintenance. Intercropping was practiced on nearly all plots with a wide variety of crops cultivated. The extent to which cultivation was possible varied as a function of available space and farmers had mixed opinions regarding the effects of integrating trees and SWC measures on crop productivity. The key point here is that whereas adoption of NRM innovations is typically seen as a dichotomous choice, it is evident that adopting farmers in Channapur have implemented and subsequently managed the wadi 'model' in different ways, giving rise to substantial variability in plot configurations and likely performance. Therefore we suggest that it is important for agroforestry adoption studies to give due consideration to the ways in which technologies are managed and adapted as a central aspect of the complex adoption process, rather than representing adoption in simplistic binary terms.

Notwithstanding the success in terms of retention, expansion and diffusion, the outcomes of this agroforestry intervention were not especially pro-poor. Adoption rates were proportionately much higher among households ranked in the upper three wealth classes, where farm sizes tended to be larger and a greater proportion of working individuals derived their primary occupation from cultivating their own land. The corresponding low level of adoption among households ranked 'poor' and 'very poor' was related to low natural capital endowments, strong aversion to risk, and proximity to a city offering alternative livelihood opportunities. However, it is worth stressing that prior to BAIF's intervention, the number of households practicing fruit-based agroforestry in Channapur was low - just eight in total - and the majority (75\%) were ranked 'rich' (Table 2). Our follow-up research found that 40 households had now adopted and just ten (25\%) were ranked 'rich', with similar numbers from the other wealth classes. Thus, it is evident that the intervention has promoted a more 
equitable distribution of agroforestry and ensured that it is not only the richest households in the village who can derive environmental and economic benefits from the integration of trees on their farms. BAIF's extension approach was deliberately inclusive, with exposure visits and on-farm demonstrations available to all interested farmers irrespective of wealth or status, and it is not clear that more could have been done to facilitate adoption by a larger proportion of poorer land-owning households. Had the project operated in the village over a longer time period - thereby allowing greater opportunity for farmers to evaluate the new practice on the lands of neighbours before making a decision - it is conceivable that more households ranked 'poor' and 'very poor' may have decided to adopt. But this is not certain and, in any case, extension projects - given typical financial and operational constraints - cannot continue indefinitely.

Although three quarters of land-owning households in Channapur had not adopted fruit-based agroforestry, $18 \%$ of all farmland deemed suitable (non-rice paddy) within the village boundaries had nonetheless been converted. Around half of this was directly attributable to the BAIF intervention; indirectly the figure was higher, since BAIF's extension effort influenced later expansion of the wadi practice, albeit in often simplified form, through the Sujala watershed project. While this is an impressive achievement considering the relative brevity of the wadi project's operational period, when viewed at landscape-scale, agroforestry coverage in Channapur resembles a patchwork effect (Fig. 4). In recent times there has been much discussion regarding the role of agroforestry in enhancing ecosystem service provision (Jose 2009; Rapidel et al. 2011). While for delivery of some ecosystem services such as carbon sequestration, it probably makes little difference how trees are distributed in the landscape, for others, such as controlling soil erosion, it can matter a great deal. Adoption of wadi agroforestry is likely to be important for individual farmers in terms of in-situ conservation of moisture and nutrients, but can a non-systematic scattering of plots in the landscape make a significant difference to large-scale soil erosion? This is arguably the most pressing environmental problem in Channapur given the associated decline in soil fertility and silting-up of water bodies. BAIF's wadi approach was voluntary, with households free to choose whether or not they wished to participate. There is strong justification for this given the ethical issues associated with more coercive approaches and the disappointing outcomes they have produced (Pretty and Shah 1997). Nevertheless, we suggest that a purely voluntary, household approach is unlikely to result in adoption that is optimised to address watershed- or landscape-scale problems. BAIF have recognised this and have been piloting an area-based approach in Gujarat that integrates individual farm-level action with community initiatives at catchment-scale (BAIF 2012). Effective collective-action, however, requires substantial investment in mobilisation and coordination (Kerr et al. 2007; Shiferaw et al. 2009), which is likely to make it both more challenging and more costly to implement.

\section{References}

Adesina AA, Chianu J (2002) Determinants of farmers' adoption and adaptation of alley farming technology in Nigeria. Agrofor Syst 55:99-112

Atangana A, Khasa D, Chang S, Degrande A (2014) Tropical agroforestry. Springer, Dordrecht

BAIF (2011) Food for work forestry programme: a study of a development prototype. BAIF Development Research Foundation, Pune

BAIF (2012) Landscape approach for rural development. BAIF Development Research Foundation, Pune

BAIF (2013) Transforming lives: BAIF's contribution to tribal development. BAIF Development Research Foundation, Pune

Barrett CB, Place F, Aboud A, Brown DR (2002) The challenge of stimulating adoption of improved natural resource management practices in African agriculture. In Barrett CB, Place F, Aboud A, (eds) Natural resource management in African agriculture: understanding and improving current practices. CABI, Wallingford, pp 1-21

Bhatt A (1990). Poverty, tribals and development: a rehabilitation approach. Manohar Publications, New Delhi 
Brook RM, Purushothaman S (2003) Introduction. In Brook RM, Purushothaman S, Hunshal C (eds) Changing frontiers: the peri-urban interface, Hubli-Dharwad, India. Books for Change, Bangalore, pp 1-10

Brook RM, Purushothaman S, Purohit S (2003) Conclusions. In Brook RM, Purushothaman S, Hunshal C (eds) Changing frontiers: the peri-urban interface, Hubli-Dharwad, India. Books for Change, Bangalore, pp 134145

Browder JO, Wynne RH, Pedlowski, MA (2005) Agroforestry diffusion and secondary forest regeneration in the Brazilian Amazon: further findings from the Rondonia Agroforestry Pilot Project (1992-2002). Agrofor Syst. 65:99-111

Chambers R, Leach M (1989) Trees as savings and security for the rural poor. World Dev 17:329-342

Dahlquist RM, Whelan MP, Winowiecki L, Polidoro B, Candela S, Harvey CA, Wulfhorst JD, McDaniel PA, Bosque-Perez NA (2007) Incorporating livelihoods in biodiversity conservation: a case study of cacao agroforestry systems in Talamanca, Costa Rica Biodivers Conserv 16:2311-2333

de Graaff J, Amsalu A, Bodnar F, Kessler A, Posthumus H, Tenge A (2008). Factors influencing adoption and continued use of long-term soil and water conservation measures in five developing countries. J Appl. Geography 28:271-280

De Schutter O (2010) Report on the right to food. UN Human Rights Council, Geneva

Douthwaite B, Keatinge JDH, Park JR (2001) Why promising technologies fail: the neglected role of user innovation during adoption. Res Policy 30:819-836

Franzel S, Scherr SJ (2002) Introduction. In Franzel S, Scherr SJ (eds) Trees on the farm: assessing the adoption potential of agroforestry practices in Africa. CABI, Wallingford, pp 1-10

Garrity D (2004) Agroforestry and the achievement of the Millennium Development Goals. Agrofor Syst. 61:517

German L, Mowo J, Kingamkono M (2006) A methodology for tracking the "fate" of technological interventions in agriculture. Agric Hum. Values 23:353-369

Gregory P, Mattingly M (2009) Goodbye to natural resource-based livelihoods? Crossing the rural/urban divide. Local Environ 14:879-890

Halkatti M, Purushothaman S, Brook RM (2003) Participatory action planning in the peri-urban interface: the twin city experience, Hubli-Dharwad, India. Environ Urbanization 15:149-158

Jerneck A, Olsson L (2013) More than trees! Understanding the agroforestry adoption gap in subsistence agriculture: Insights from narrative walks in Kenya. J Rural Stud 32:114-125

Jose S (2009) Agroforestry for ecosystem services and environmental benefits: an overview. Agrofor Syst 76:110

Keil A, Zeller M, Franzel S (2005) Improved tree fallows in smallholder maize production in Zambia: do initial testers adopt the technology? Agrofor Syst 64:225-236

Kerr J, Milne G, Chhotray V, Baumann P, James AJ (2007) Managing watershed externalities in India: theory and practice. Environ Dev Sustainability 9:263-281

Kiptot E, Hebinck P, Franzel S, Richards P (2006) Sharing seed and knowledge: farmer to farmer dissemination of agroforestry technologies in western Kenya. Agrofor Syst 68:167-179

Kiptot E, Hebinck P, Franzel S, Richards P (2007) Adopters, testers or pseudo-adopters? Dynamics of the use of improved tree fallows by farmers in western Kenya. Agric Syst 94:509-519 
Mahajan S, Newale M, Pednekar P (2002) Orchard development sets the tone of tribal development. Dev Pract 12:86-92

McIntyre BD, Herren HR, Wakhungu J, Watson RT (eds) (2009) Agriculture at a crossroads: international assessment of agricultural knowledge, science and technology for development (IAASTD). Island Press, Washington DC

Meijer SS, Catacutan D, Ajayi OC, Sileshi, GW, Nieuwenhuis M (2014) The role of knowledge, attitudes and perceptions in the uptake of agricultural and agroforestry innovations among smallholder farmers in subSaharan Africa. Int J Agric Sustainability. doi:10.1080/14735903.2014.912493

Mercado AR, Patindol M, Garrity DP (2001) The Landcare experience in the Philippines: technical and institutional innovations for conservation farming. Dev Pract 11:495-508

Mercer DE (2004) Adoption of agroforestry in the tropics: a review. Agrofor Syst. 61-62:311-328

Mercer DE, Haggar J, Snook A, Sosa M (2005) Agroforestry adoption in the Calakmul Biosphere Reserve, Campeche, Mexico. Small-scale For Econ Manag Policy 4:163-184

Milne G (2007) Karnataka Watershed Development "Sujala" Project: innovation in participatory watershed development to improve natural resource productivity and rural livelihoods. Livelihoods Learning Series 1, Note No. 3. World Bank, Washington DC

Nunan F, Shindhe KC (2003) Urbanisation leading to changing land use trends. In Brook RM, Purushothaman S, Hunshal C (eds) Changing frontiers: the peri-urban interface, Hubli-Dharwad, India. Books for Change, Bangalore, pp 11-30

Pattanayak SK, Mercer DE, Sills E, Yang JC (2003) Taking stock of agroforestry adoption studies. Agrofor Syst. 57:137-150

Pretty JN, Shah P (1997) Making soil and water conservation sustainable: from coercion and control to partnerships and participation. Land Degrad Dev 8:39-58

Pretty J, Toulmin C, Williams S (2011) Sustainable intensification in African agriculture. Int J Agric Sustainability, 9(1), 5-24

Rapidel B, Le Coq JF, DeClerk AJ, Beer J (2011) Measurement and payment of ecosystem services from agriculture and agroforestry: new insights from the Neotropics. In Rapidel B, DeClerk AJ, Le Coq JF, Beer J (eds) Ecosystem services from agriculture and agroforestry: measurement and payment. Earthscan, London.

Sanchez PA (1995) Science in agroforestry. Agrofor Syst. 30:5-55

Scherr SJ, Müller EU (1990) Evaluating agroforestry interventions in extension projects. Agrofor Syst. 11:259280

Scherr SJ, Müller EU (1991) Technology impact evaluation in agroforestry projects. Agrofor Syst. 13:235-257

Shiferaw BA, Okello J, Reddy RV (2009) Adoption and adaptation of natural resource management innovations in smallholder agriculture: reflections on key lessons and best practices. Environ Dev Sustainability 11:601619

Tachikawa T, Hato M, Kaku M, Iwasaki A (2011) The characteristics of ASTER GDEM version 2, International Geoscience and Remote Sensing Symposium (IGARSS), Vancouver, BC, Canada, July 24-29, 2011.

Tripp R (2005) The performance of low external input technology in agricultural development: a summary of three case studies, Int J Agric Sustainability 3:143-153 
Wambugu C, Place F, Franzel S (2011) Research, development and scaling-up the adoption of fodder shrub innovations in east Africa. Int J Agric Sustainability 9:100-109 


\section{TABLES}

Table 1 Indicators and outcomes of a participatory monitoring and evaluation exercise held in 2005 with 25 wadi adopting farmers. Source: Unpublished project documentation.

\begin{tabular}{lllll}
\hline Indicator & + & - & - & Reasons \\
\hline $\begin{array}{l}\text { Changing attitudes } \\
\text { towards agroforestry }\end{array}$ & 23 & 2 & 0 & $\begin{array}{l}\text { Two farmers felt that the work required in caring for trees in } \\
\text { drought conditions was onerous, but the rest thought it worthwhile } \\
\text { considering future benefits. } \\
\text { According to the group, originally other farmers in the village had } \\
\text { thought they were "crazy" to plant trees on their plots and had } \\
\text { laughed at them. Now the same people expressed regret that they } \\
\text { had not been involved. }\end{array}$ \\
$\begin{array}{llllll}\text { Increased capacity to } \\
\text { manage agroforestry }\end{array}$ & 25 & 0 & 0 & $\begin{array}{l}\text { Before the intervention most farmers had no confidence in } \\
\text { establishing fruit trees. Now it is seen to be possible with the } \\
\text { integration of low-cost SWC practices. }\end{array}$ \\
\hline $\begin{array}{l}\text { Changes in crop } \\
\text { development }\end{array}$ & 25 & 0 & 0 & $\begin{array}{l}\text { Composting and mulching is a normal part of the management } \\
\text { system and all farmers observed signs that crops benefited from } \\
\text { improvements in soil fertility. }\end{array}$ \\
\hline $\begin{array}{l}\text { Changes in soil moisture } \\
\text { retention }\end{array}$ & 25 & 0 & 0 & $\begin{array}{l}\text { Farmers observed an extended sowing period and also crops in } \\
\text { wadi were seen to resist the dry weather better than crops in } \\
\text { neighbouring fields. }\end{array}$ \\
\hline $\begin{array}{l}\text { Increased fodder } \\
\text { availability. }\end{array}$ & 24 & 1 & 0 & $\begin{array}{l}\text { One farmer had not yet felt the benefit from very recently planted } \\
\text { fodder species. Others are confident about sustained availability of } \\
\text { fodder even in the dry summer months. }\end{array}$ \\
\hline
\end{tabular}

Table 2 Temporal pattern and rate of adoption by wealth class

\begin{tabular}{|c|c|c|c|c|c|c|c|c|c|c|}
\hline \multirow[b]{2}{*}{ Wealth rank } & \multirow{2}{*}{$\begin{array}{l}\text { Eligible } \\
\text { land- } \\
\text { owning } \\
\text { HHs }\end{array}$} & \multicolumn{7}{|c|}{ Year of 1st adoption of fruit-based agroforestry } & \multirow{2}{*}{$\begin{array}{l}\text { Total AF } \\
\text { adopting } \\
\text { HHs }\end{array}$} & \multirow{2}{*}{$\begin{array}{l}\text { Overall } \\
\text { rate of } \\
\text { adoption }\end{array}$} \\
\hline & & $\begin{array}{l}\text { Pre- } \\
2002\end{array}$ & 2002 & 2003 & 2004 & 2005 & 2006 & 2007 & & \\
\hline Rich & 15 & 6 & 4 & - & - & - & - & - & 10 & $67 \%$ \\
\hline Upper Mid & 15 & - & $6^{\mathrm{b}}$ & & - & - & - & - & 6 & $40 \%$ \\
\hline Lower Mid & 32 & - & 4 & 1 & $3^{\mathrm{b}}$ & 1 & - & - & 9 & $28 \%$ \\
\hline Poor & 48 & - & 2 & 3 & 3 & 1 & - & - & 9 & $19 \%$ \\
\hline Very Poor & 59 & 2 & 2 & - & - & 1 & - & 1 & 6 & $10 \%$ \\
\hline Unranked & 2 & - & - & - & - & - & - & - & 0 & $0 \%$ \\
\hline Total & 171 & 8 & $18^{\mathrm{a}}$ & 4 & 6 & 3 & 0 & 1 & 40 & $23 \%$ \\
\hline \multicolumn{11}{|c|}{$\begin{array}{l}\text { a Five households owned orchards that predated the project but also adopted wadi using BAIF inputs in } 2002 \\
(\mathrm{n}=23 ; 18+5) \\
{ }^{\mathrm{b}} \text { Two households (one in } 2002 \text { and one in 2004) adopted during the BAIF project years (2002-2004) but usec } \\
\text { their own resources }\end{array}$} \\
\hline
\end{tabular}


Table 3 Rate of adoption by landholding class

\begin{tabular}{l|c|c|c}
\hline \multicolumn{1}{c|}{ Landholding class } & Total HHs in class & $\begin{array}{c}\text { Agroforestry adopting HHs } \\
\text { in class }\end{array}$ & Overall rate of adoption \\
\hline$\geq 4$ ha. & 12 & 5 & $42 \%$ \\
\hline$\geq 3<4$ ha. & 12 & 5 & $42 \%$ \\
\hline$\geq 2<3$ ha. & 15 & 6 & $40 \%$ \\
\hline$\geq 1<2$ ha. & 56 & 14 & $25 \%$ \\
\hline$<1$ ha. & 76 & 10 & $13 \%$ \\
\hline Landless & 81 & 0 & $23 \%$ \\
\hline Total & 252 & 40 & \\
\hline${ }^{a}$ Excludes landless households & & \\
\hline
\end{tabular}

Table 4 Extent of agroforestry plots by plot type

\begin{tabular}{l|c|c|c}
\hline Plot type & No. of plots & Total area (ha) & Mean plot area (ha)* \\
\hline Pre-existing plots $(<2002)$ & 9 & 18.8 & $2.0(2.3)$ \\
\hline BAIF-mediated wadi plots & 38 & 20.1 & $0.5(0.3)$ \\
\hline Non-BAIF plots $(2002>)$ & 17 & 7.0 & $0.4(0.4)$ \\
\hline TOTAL & 64 & 45.9 & $0.7(1.0)$ \\
\hline
\end{tabular}

* Values in parentheses are standard deviations from the mean 
Table 5 Tree species and utilisation

\begin{tabular}{|c|c|c|c|c|}
\hline & Scientific name & Common name & BAIF & Utilisation \\
\hline \multirow{11}{*}{ 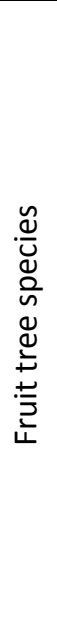 } & Anarcardium occidentale & Cashew & $\checkmark$ & Fruits; nuts \\
\hline & Carica papaya & Papaya & $\mathbf{x}$ & Fruits \\
\hline & Cocos nucifera & Coconut & $\mathbf{x}$ & Fibre; fruits; fuel; leaves; oil \\
\hline & Citrus $x$ limon & Lemon & $\mathbf{x}$ & Fruits \\
\hline & Mangifera indica & Mango & $\checkmark$ & Fruits; timber \\
\hline & Manilkara zapota & Sapodilla / Sapota & $\checkmark$ & Fruits \\
\hline & Murraya koenigii & Curry leaf & $\checkmark$ & Edible leaves \\
\hline & Musa spp. & Banana & $\mathbf{x}$ & Fruits; leaves \\
\hline & Psidium guajava & Guava & $\mathbf{x}$ & Fruits \\
\hline & Phyllanthus emblica & Amla & $\checkmark$ & Fruits \\
\hline & Tamarindus indica & Tamarind & $\checkmark$ & Edible pods; timber \\
\hline \multirow{13}{*}{ 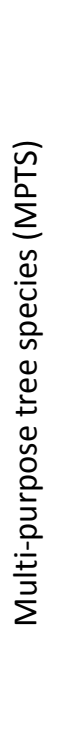 } & Acacia spp. & Babul & $\checkmark$ & Fuel \\
\hline & Azadirachta indica & Neem & $\mathbf{x}$ & Fuel; medicine; oil; timber \\
\hline & Casurina equisetifolia & She-oak / Beach oak & $\checkmark$ & Fuel; poles \\
\hline & Dalbergia sisoo & Indian rosewood & $\checkmark$ & Fodder; fuel; timber \\
\hline & Erythrina indica & Indian coral tree & $\checkmark$ & Fodder; fuel; poles \\
\hline & Eucalyptus spp. & Eucalyptus & $\checkmark$ & Fuel; medicine; poles \\
\hline & Gliricidia sepium & Mexican lilac & $\sqrt{ }$ & Fodder; fuel; green manure \\
\hline & Grevillea robusta & Silver oak & $\checkmark$ & Fuel; timber \\
\hline & Leuceana leucocephela & Subabul & $\checkmark$ & Fodder; fuel; green manure; \\
\hline & Moringa oleifera & Drumstick & $\checkmark$ & Edible leaves and pods \\
\hline & Sesbania sesban & Egyptian pea & $\checkmark$ & Fodder; fuel; green manure \\
\hline & Senna siamea & Kassod / Cassod & $\checkmark$ & Fuel; green manure; poles \\
\hline & Tectona grandis & Teak & $\checkmark$ & Poles; timber \\
\hline
\end{tabular}


Table 6 Reasons for non-adoption of agroforestry

\begin{tabular}{ll}
\hline Reasons for non-adoption & $\begin{array}{c}\text { Percentage of households } \\
(\mathrm{n}=17)\end{array}$ \\
\hline During BAIF project years (2002-2004) & $41 \%$ \\
\hline Water insecurity & $35 \%$ \\
\hline Small size of plot / risk of reduced crop yields & $24 \%$ \\
\hline Labour shortage & $18 \%$ \\
\hline Tenure insecurity & $12 \%$ \\
\hline Children not interested & $12 \%$ \\
\hline Shared land holding & \\
\hline Independently of BAIF in subsequent years & $41 \%$ \\
\hline Lack of capital & $35 \%$ \\
\hline Labour shortage & $18 \%$ \\
\hline Tenure insecurity & $12 \%$ \\
\hline Not interested in adopting & $6 \%$ \\
\hline Land leased out & $6 \%$ \\
\hline Small size of plot / risk of reduced crop yields & \\
\hline
\end{tabular}

NB: Totals add up to more than 100 because some farmers gave multiple reasons 


\section{FIGURES}

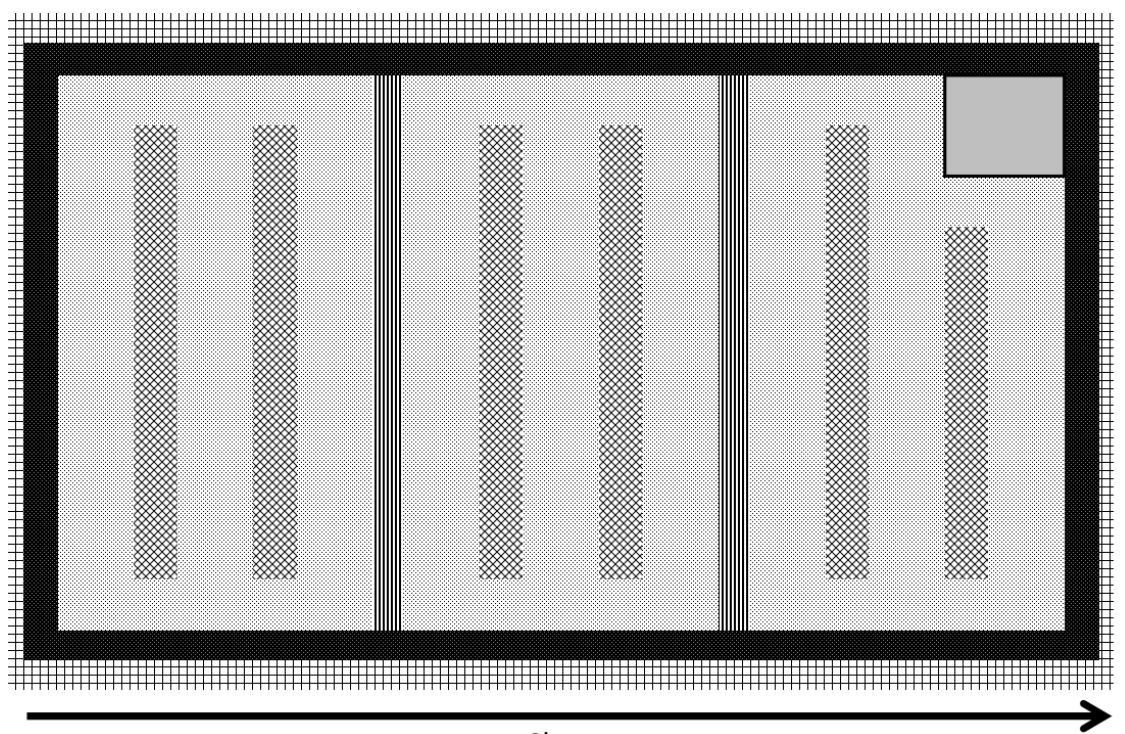

Intercrops

Fruit trees

Multi-purpose trees

Trench-cum-bund

Farm pond

Dry fence

Fig. 1 Schematic layout of BAIF Wadi model

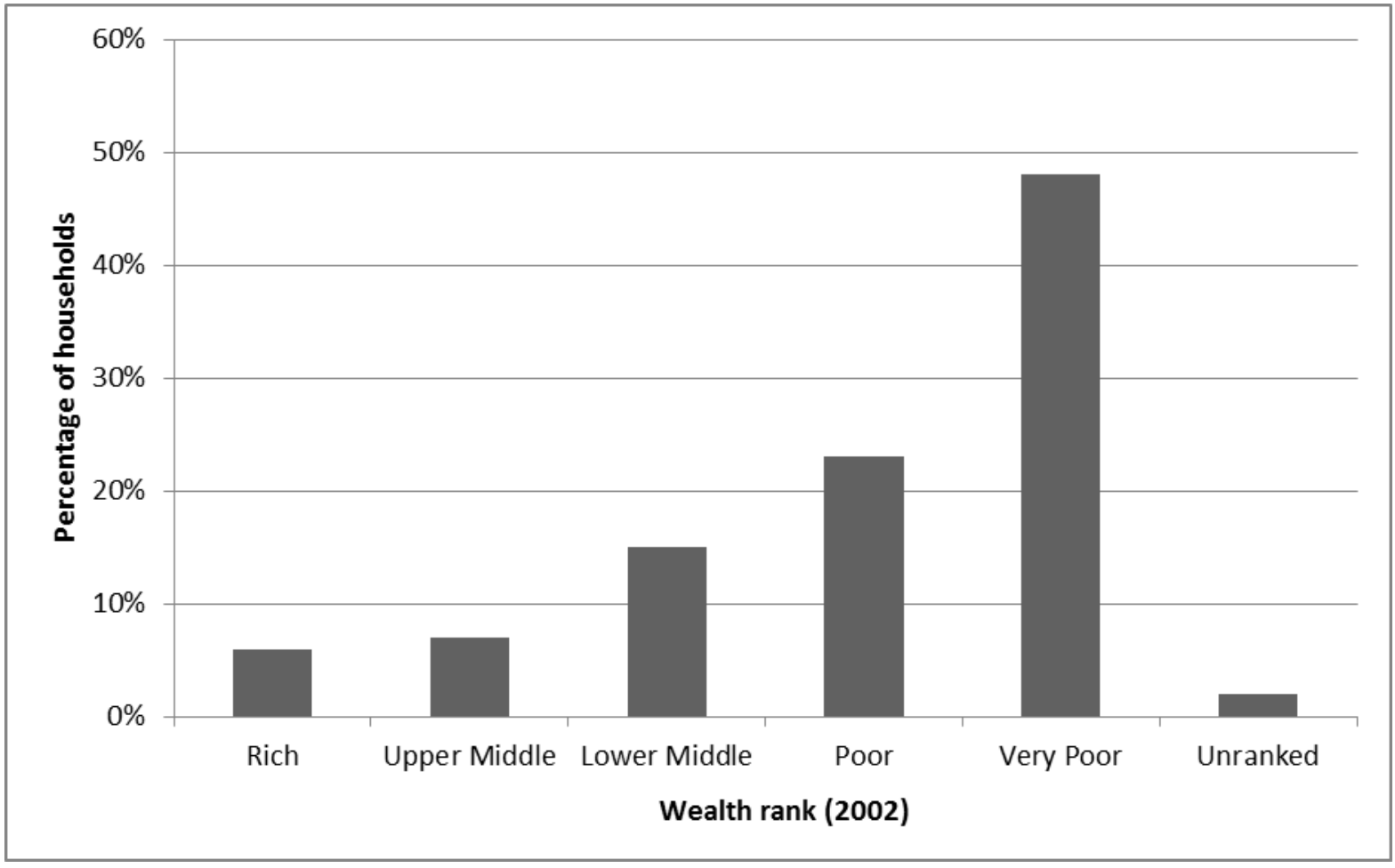

Fig. 2 Participatory wealth ranking of households in Channapur 


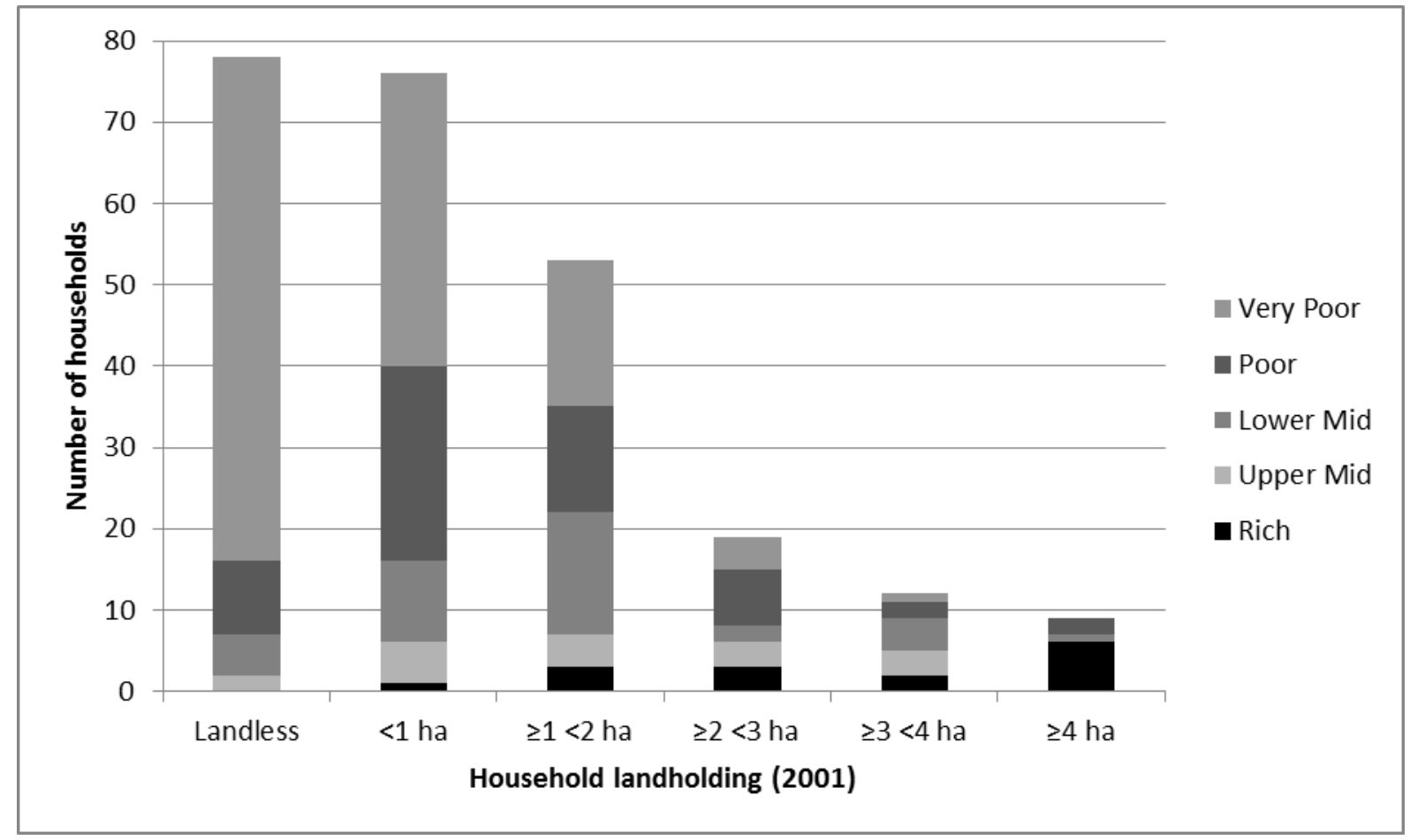

Fig. 3 Distribution of household landholdings in Channapur by size class and wealth rank 


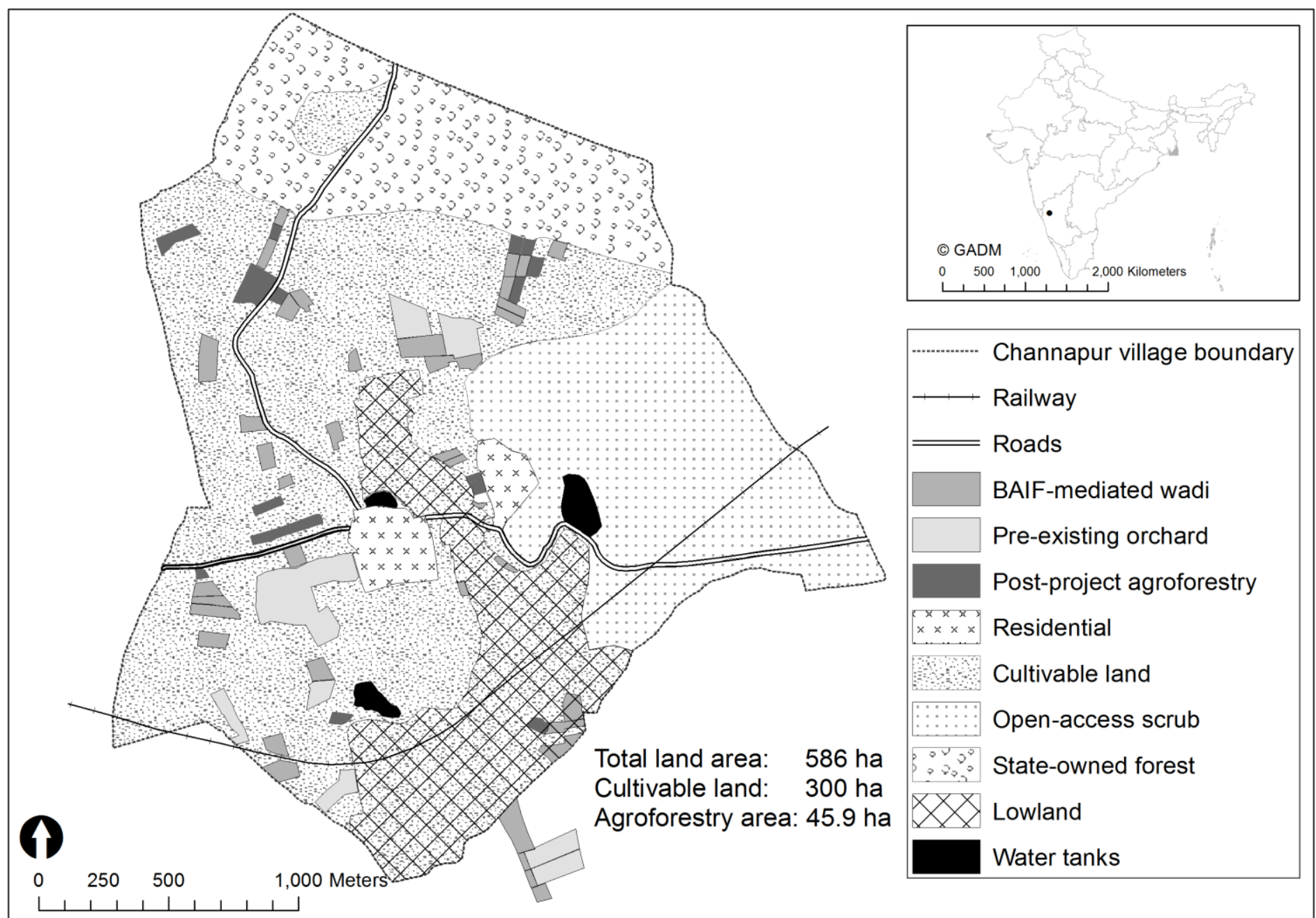

Fig. 4 Spatial distribution and extent of agroforestry in Channapur 


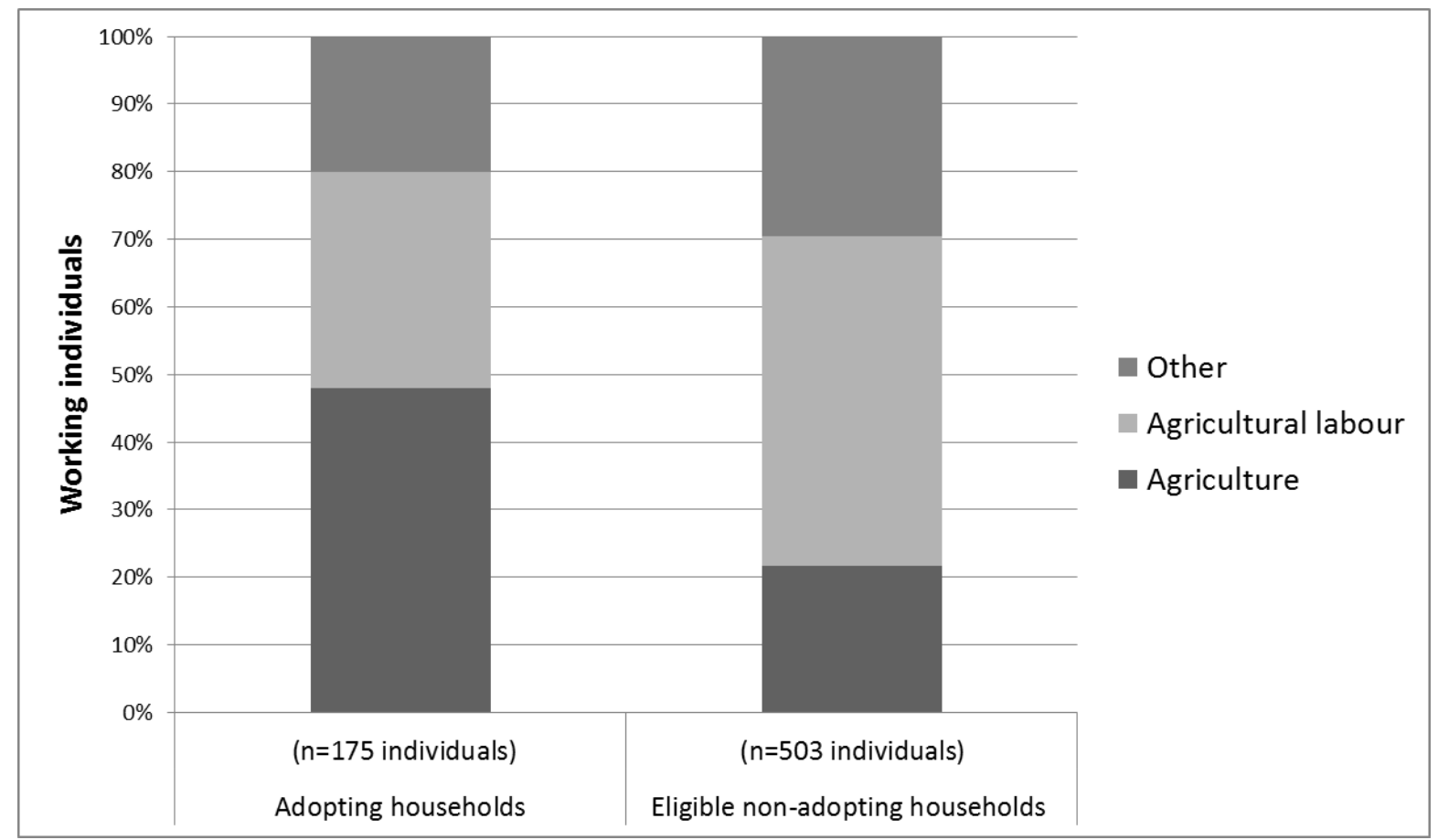

Fig. 5 Primary occupation, in 2001, of all working individuals within the 40 adopting households and 131 eligible non-adopting households 


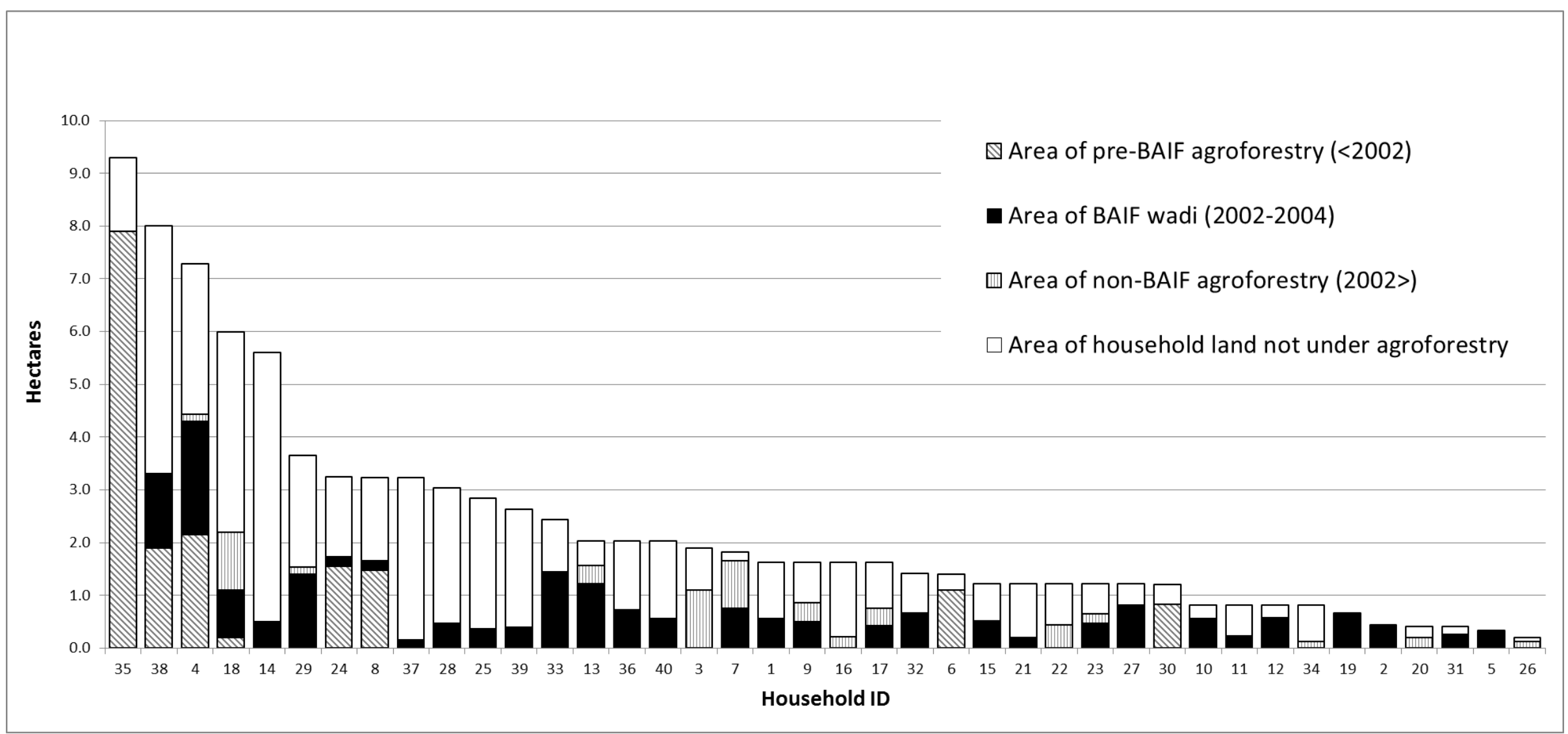

